\title{
Hypolipidemic Effect of Sumac (Rhus Coriaria L) Fruit Powder and Extract on Rats Fed High Cholesterol Diet
}

\author{
Nagib, R.M
}

Department of Home Economics, Faculty of Specific Education, Mansoura University, Egypt

4 sumac fruit powder and extract under various concentrations against hyperlipidemia. Chemical composition, minerals content, total phenolic, flavonoid and antioxidant activity were determined. Forty two male albino rats were used in the study, they were distributed into six groups, ( $n=7$ rats). Group 1 was fed on standard diet as a negative control (-ve). The other five groups were fed on basal diet containing 4\% cholesterol and 1\% cholic acid (HCD) for 8 weeks to induce hypercholesterolemia. Group 2 (positive control group) was fed on HCD only. Groups 3 and 4 were fed on HCD + sumac powder at 5 and $10 \%$ per $\mathrm{kg}$ diet. Groups 5 and 6 were fed on HCD + sumac extract at 0.5 and $1.0 \mathrm{~g} / \mathrm{kg}$ b.w/day orally respectively. Results recorded that sumac is a source of dietary fibers, minerals, flavonoid, phenolic and antioxidants activity. The results indicated that positive group (+ve) showed significantly higher level of serum $T C, T G, L D L-c, V L D L-c$, urea, uric acid, creatinine, $A L T, A S T, A L P, T N F \alpha, M D A$ and acetyl cholinesterase (AChE) and decrease in serum $H D L-c$ and $S O D$, while the groups treated with sumac powder at $5 \%$ and $10 \%$ and sumac extract at 0.5 and $1.0 \mathrm{~g}$ can reduce blood cholesterol and other lipids and improve liver and kidney function especially the level of $10 \%$ powder and $1.0 \mathrm{~g}$ extract compared to positive group (+ve). It could be concluded that, fortified diets with $10 \%$ sumac powder and those which received sumac extract at $1.0 \mathrm{~g}$ had the best effect on hypercholesterolemic rats.

Key words: Sumac, hypercholesterolemia, serum lipids, DPPH, kidney and liver function. 
Hypolipidemic Effect of Sumac (Rhus Coriaria L) Fruit Powder and Extract on Rats Fed High Cholesterol Diet

Nagib, R.M

\section{INTRODUCTION}

Sumac

(Rhus

coriaria L., family Anacardiaceae) is one of the most popular spices in Mediterranean and Arabic countries, which is obtained by crushing the dried fruits. Sumac is used in traditional medicine for its antibacterial and antioxidant effect (Aliakbarlu et al., 2013 ; Ali-Shtayeh et al., 2013 and Kossah et al., 2013), antifungal (Onkar et al., 2011), anti-inflammatory (Panico et al., 2009), DNA protective (Chakraborty $\boldsymbol{e t}$ al., 2009), hypoglycemic (Golzadeh et al., 2012 and Anwer et al., 2013), and hypolipidemic activities (Madihi et al., 2013).

Sumac is a rich source of tannins, phenolic compounds, oleic and linoleic acids, vitamins, minerals, anthocyanins and organic acids (Zargham and Zargham, 2008; Kossah, et al., 2009 and Kossah, et al., 2010).

\begin{tabular}{lr}
\multicolumn{3}{c}{ Water extracts of } \\
sumac have & marked \\
antioxidant activity & against
\end{tabular}

lipid peroxidation and free radicals, it protect humans against oxidative DNAdamage (Chakraborty et al., 2009 and Bursal and Koksal, 2011).

Hypercholesterolemi $\mathrm{a}$ is a disturbance of lipid metabolism caused by an increase of plasma concentrations of the various lipid and lipoprotein fractions, and considered as a major risk factor for hyperlipidemia disease and hypercholesterolemia.

Hyperlipidemia have been classifed as one of the largest risk factors caused to the expansion, and riskiness of coronary heart diseases (Kolovou et al., 2005; Reiner and Tedeschi, 2006; Roberts et al., 2006 and Zainab Sajid et al., 2016). The aim of the present work was to study the hypolipidemic effect of sumac fruit powder and extract on rats fed high cholesterol diet. 
Hypolipidemic Effect of Sumac (Rhus Coriaria L) Fruit Powder and Extract on Rats Fed High Cholesterol Diet

Nagib, R.M

MATERIALS \& METHODS

Materials

Plant: Sumac (Rhus coriaria

L.) fruits were obtained from Medical Herbs Center, Cairo, Egypt.

Chemicals:

Cholesterol, cholic acid, casein, cellulose, all vitamins and minerals ingredients were purchased from ElGomhoryia Company for chemicals, El-Mansoura City, Egypt. Kits were obtained from

Biodiagnostic Company, Giza, Egypt.

Experimental

animals:

Forty two male Sprague Dawely rats weighing 180 $\pm 10 \mathrm{~g}$ were obtained from Agricultural Research Center, Giza, Egypt.

\section{Methods}

Preparation of raw material

Sumac fruits were ground into powder then stored in polyethylene bags at $4^{\circ} \mathrm{C}$ until used.

Preparation of sumac Aqueous Extract:
$30 \mathrm{~g}$ of sumac powdered were extracted with hot distilled water and cooled for $30 \mathrm{~min}$, and filtrated twice. Extract was concentrated to dryness in vacuum, and stored in refrigerator according to (Ghaleb et al., 2006).

Chemical analysis of raw materials:

Moisture, protein, crude fibers, fat content and ash contents were analyzed as described in the A.O.A.C (2000). Total carbohydrates were calculated by the difference. Minerals content included $(\mathrm{Ca}, \mathrm{P}, \mathrm{K}, \mathrm{Mg}$, $\mathrm{Fe}$ \& $\mathrm{Zn})$ were determined according to Chapman \& Pratt (1978). After complete digestion the minerals were determined using Unicam atomic absorption Spectrophotometer. Total phenole and flavonoid were determined according to Singleton et al., (1999) and Zhishen et al., (1999). Antioxidant activity assayed by the 1, 1-diphenyl-2picryl-hydrazyl (DPPH) method of Brand-Wiliams et al., (1995) with some 
Hypolipidemic Effect of Sumac (Rhus Coriaria L) Fruit Powder and Extract on Rats Fed High Cholesterol Diet

Nagib, R.M

modification. The extract $(0.5$ and $1.0 \mathrm{~g})$ in methanol (1 ml) was blended with $4 \mathrm{ml}$ of $\quad 0.004 \%$ methanolic solution of DPPH. The blend was shaken strongly and left to stand for $30 \mathrm{~min}$ in dark and the absorbance was then measured at $517 \mathrm{~nm}$.

The percent of DPPH decrease according to the equation:

Antiradical activity =Absorbance of controlAbsorbance of sample/Absorbance of control

Biological Experiment:

Standard Diet: ordinary diet was prepared according to AIN-93 guidelines (Reeves et al., 1993).

\section{Induction}

of

\section{Hypercholesterolemia:}

Hypercholesterolemia was induced in rats by feeding high cholesterol diet $(4 \%$ cholesterol and $1 \%$ cholic acid) in normal diet for 8 weeks (Kamesh and Sumathi, 2012). Serum cholesterol level was monitored after two weeks from each rat to make sure the induction of hypercholesterolemia.

\section{Experimental design:}

Animals were reserved in the laboratory in plastic cages under stable temperature $\left(24 \pm \quad 2^{\circ} \mathrm{C}\right)$, and fed on standard diet for seven days for adaptation period, water was supplied ad-libitum , then rats were distributed into six groups ( $\mathrm{n}=7$ rats) as follow :

Group 1: Control normal group: Rats were fed on basal diet only without any treatment during the experimental period.

Group 2: Control positive group: Rats were fed on high cholesterol diet (HCD) only without any treatment.

Group 3: Rats were fed with HCD + 5\% sumac powder per $\mathrm{kg}$ diet /daily after two weeks from the onset of induction of hypercholesterolemia.

Group 4: Rats were fed with HCD $+10 \%$ sumac powder per $\mathrm{kg}$ diet /daily after two weeks from the 
Hypolipidemic Effect of Sumac (Rhus Coriaria L) Fruit Powder and Extract on Rats Fed High Cholesterol Diet

Nagib, R.M

onset of induction of hypercholesterolemia.

Group 5: Rats were fed with $\mathrm{HCD}+0.5 \mathrm{~g} / \mathrm{kg}$, b.w /day sumac extract given orally by stomach tube after two weeks from the onset of induction of

hypercholesterolemia.

Group 6: Rats were fed with $\mathrm{HCD}+1.0 \mathrm{~g} / \mathrm{kg}$, b.w /day sumac extract given orally by stomach tube after two weeks from the onset of induction of hypercholesterolemia.

During the experimental period (8 weeks), feed intake, body weight gain and Feed efficiency ratio (FER) were determined according to Chapman et al. (1950).

\section{Biochemical analysis:} Serum total cholesterol, triacylglycerol, high density lipoprotein, low density lipoprotein and very low density lipoprotein were determined by the methods of Richmond (1973); Fassati and Princepe (1982); Gordon, (1977) and Friedewald et al. (1972) respectively. An atherogenic index was calculated by dividing TC / HDLc according to Castelli and levitear (197). (ALT), (AST) and alkaline phosphates (ALP) were assayed by Reitman and Frankel (1957) and Kind and King (1954). Serum uric acid, urea nitrogen and creatinine were determined by the methods of Fossati et al. (1980), Patton and Crouch, (1977) and Bohmer (1971). Determine tumor necrosis factor (TNF- $\alpha$ ), according to Lin et al. (1998). Superoxide dismutase enzymes (SOD) and malondialdehyde (MDA) were estimated by Beuchamp and Fridovich, (1971) and Ohkawa et al., (1979). Acetylcholinesterase (AchE) activity was determined by Knedel and Boottger, (1967).

\section{Statistical analysis:}

Data were statistically analyzed of variance "ANOVA" test at $(\mathrm{P} \leq 0.05)$ according to Snedecor and Cochran (1967). 
Hypolipidemic Effect of Sumac (Rhus Coriaria L) Fruit Powder and Extract on Rats Fed High Cholesterol Diet

Nagib, R.M

\section{RESULTS \& DISCUSSION}

The

chemical

composition of sumac are illustrated in table (1).The moisture, protein, fat, ash, carbohydrate and fiber , ratios were $(13.65,4.93$, $16.88,5.09,59.45$ and 19.61 $\mathrm{g} / 100 \mathrm{~g}$ ) respectively. The results in this study are similar to that obtained by Özcan

and

Haciseferogullari, (2004) and Kizil and Turk, (2010). Furthermore sumac is rich in proteins, essential oils, fatty acids, and fiber (Shabir, 2012).

The minerals composition of sumac was presented in table (2). The results of calcium, phosphorus, potassium, magnesium, iron and zinc were $(398.9,123.7,812.5$, $85.67, \quad 15.32$ and 2.03 $\mathrm{mg} / 100 \mathrm{~g}$ ) respectively. These data are confirmed with Kossah et al., (2009) who reported that sumac fruits could be used in the human diet to supply the required mineral elements. Many other studies indicated that $\mathrm{K}, \mathrm{Ca}, \mathrm{Mg}$, and $\mathrm{Ph}$ were found in sumac fruit (Barakat et al., 2003; Özcan and

Hacisefaerogullari, 2004; Özcan and Akbulut, 2007; Kizil and Turk, 2010).

Data in table (3), showed that total phenol, flavonoid and scavenging effect of sumac extract on $\mathrm{DPPH}$, the ratios of total phenol and flavonoid were (4836 and $769 \mathrm{mg} / 100 \mathrm{~g}$ ) respectively, while the DPPH radical-scavenging activity of sumac extract was $(11.56 \mathrm{mmol} / \mathrm{ml})$. The results in this study are similar to that obtained by Mavlyanov et al., (1997) who revealed that sumac's fruit rich in flavones, phenolic acids, hydrolysable tannins, anthocyanin and fatty acids. Sumac water extracts showed the strongest antioxidant activity (Pourahmad, 2010 ; Bursal and Köksal, 2011 and Aliakbarlu et al.,2013 ).

Data in Table

could be observed that there were significant increases in FI and BWG for control positive group in comparison 
Hypolipidemic Effect of Sumac (Rhus Coriaria L) Fruit Powder and Extract on Rats Fed High Cholesterol Diet

Nagib, R.M

to the negative control (-ve). Groups fed on the hypercholesterolemic diet (HCD) containing sumac fruits powder at 5 and $10 \%$ and those which received the extract at concentrations 0.5 and $1.0 \mathrm{~g} / \mathrm{kg} \quad$ showed improvment in FI and BWG compared to the negative control (-ve). The results recorded that FER of positive group (+ve) (hypercholesterolemic rats) was decreased compared with the negative control group, while groups treated with sumac powder and extract showed increase in FER comparable with the positive control. These data are in accordance with Kosar et al., (2006) who demonstrated that sumac is rich in tannins; tannins present in sumac are hydrolysable, susceptible to cleavage by hydrolysis and have small molecular size. Their small size has made them to be easier to digest and absorb and have many health benefits. Also Kossah et al., (2009) who indicated that sumac species can be considered as potential sources of dietary fiber which is helpful in alleviating gastro-intestinal disorders.

The obtained data in Table (5) indicated that positive group (+ve) showed a marked significant increase in TC, TG, LDL-c, VLDL-c and Atherogenic indices. However it showed marked reduction in HDL-c compared with the negative control (-ve). Our results indicated that reduction of TC, TG, LDL-c ,VLDL-c and Cholesterol/HDLc, associated with elevation of HDL-c in rats fed on HCD fortified with sumac powder at 5 and $10 \%$ and the orally treated with extract at concentrations 0.5 and 1.0 $\mathrm{g} / \mathrm{kg}$ compared with the positive control

Furthermore all treated groups with sumac powder and extract showed no significant difference in cholesterol/HDL-c compared with the negative control group (-ve). These results are confirmed with Mansoob, (2012) mentioned that the 
Hypolipidemic Effect of Sumac (Rhus Coriaria L) Fruit Powder and Extract on Rats Fed High Cholesterol Diet

Nagib, R.M

hypocholesterolemic action of sumac may be owing to its polyphenolic components. Polyphonols have been shown to lower the inverse cholesterol transport, minimize the intestinal cholesterol absorption and elevated bile acid excretion. Sumac fruit extract decreased the high serum lipid levels (Mohammadi et $a l ., 2010$ and Shafiei, et al., 2011).

Results presented in Table (6) summarize the effect of sumac powder and extract at different ratios on serum uric acid, urea and creatinine in rats fed HCD .The positive control group recorded significant high level in serum uric acid, urea and creatinine in comparison to a negative control (-ve). Results revealed that there was non-significant difference in creatinine among negative control group and other treated groups. While the rats fed on supplemented diet with sumac powder and received extract showed significant decrease values of serum uric acid, urea and creatinine compared with positive group (+ve). The best improvement of all parameters was observed in groups treated with sumac powder at $10 \%$ and sumac extract at $1.0 \mathrm{~g}$. These results are in parallel with those obtained by Mahidi et al., (2013) showed that sumac extract decreased uric acid level. Sumac is rich in strong antioxidants called tannins, flavonoids, anthocyanins and phenolic acids (Al-Jassabi \& Azirun, 2010; Pourahmad et al., 2010 and Abu-Reidah et al., 2015).

Results in Table (7) indicated that the positive control showed a significantly higher in AST, ALT and ALP in comparison to a negative control (-ve). Our results indicated that the high levels of AST and ALT in serum are indicators for liver dysfunction. These findings are in agreement with Al-Dosari, (2011) who revealed that rats fed on HCD for 70 day showed significantly higher levels in serum liver enzymes. In this 
Hypolipidemic Effect of Sumac (Rhus Coriaria L) Fruit Powder and Extract on Rats Fed High Cholesterol Diet

Nagib, R.M

study all groups treated with sumac powder and extract showed significantly lower of AST, ALT and ALP comparable with positive group (+ve). Phenolic compounds and anthocyanins, present in the sumac have anti-oxidant effect against free radicals caused by HCD. The results in this study are similar to that obtained by Attaby et al., (2013) and Madihi et al., (2013) revealed that sumac lowered significantly the levels of AST and ALT. In this respect, the aqueous extract of sumac fruit showed hepatoprotective activity against cytotoxicity of oxidative stress (Abbass et al., 2012).

Results in Table (8) revealed that positive group (+ve) showed a significantly lower level of SOD activity while it recorded significantly higher level of TNF- $\alpha$, MDA and Acetylcholinesterase (AchE) as compared to the negative control (-ve). These results are agree with Derosa et al., (2015) who reported that mice fed on high fat diet exhibited increase in TNF- $\alpha$ plasma level . All treated groups with sumac fruits powder at 5 and $10 \%$ and groups that received extract at concentrations 0.5 and 1.0 $\mathrm{g} / \mathrm{kg}$ showed improvment in SOD while it showed a significantly lower levels of TNF- $\alpha$ MDA and Acetylcholinesterase (AchE) compared with the positive group (+ve). These results matches with that of Pourahmad et al. (2010), who demonstrated that the Malondialdehyde formation was significantly higher following reactive oxygen species (ROS) formation and aqueous extracts of sumac fruit inhibit both malondialdehyde formation and cytotoxicity. Furthermore Mohammadi et al., (2010) and Bursal and Koksal, (2011) indicated that sumac extract increased superoxide dismutase and catalase activities. Others demonstrated that sumac extract $(300 \mathrm{mg} / \mathrm{kg}$ per animal) could act on the oxidative stress by 
Hypolipidemic Effect of Sumac (Rhus Coriaria L) Fruit Powder and Extract on Rats Fed High Cholesterol Diet

Nagib, R.M

decreasing MDA and significantly increased the level of GSH and CAT activity (Beretta et al., 2009; Darwish., 2011 and Aliakbarlu et al., 2013). Also Singh et al.,(2014) indicated that (AChE) was significantly higher in animals fed on high fat diet, hence reduction acetylcholine needed for memory and learning.

\section{CONCLUSION}

In conclusion, sumac powder and extract at different ratios resulted in significant improvement in lipids profile, liver and kidney functions and antioxidant parameters in hypercholesterolemic rats.

\section{REFERENCES}

Abbass MM; Mahmoud AH; Hussein MMA and Gabr SA (2012):

Assessment of

Antioxidant Changes of Aged Rats Treated With Sumac Extract $J$. of Amer. Sci., 8(4): 553558.
Abu-Reidah I.M; AliShtayeh MS; Jamous RM; Arráez-Román D and Segura-Carretero A(2015): HPLC-DAD-ESIMS/MS screening of bioactive components from Rhus coriaria L. (Sumac) fruits. Food Chem., 166: 179-191.

\section{Al-Dosari M (2011):}

Hypolipidemic and antioxidant activities of avocado fruit pulp on high cholesterol fed diet in rats. Afr. J. Pharm. Pharmacol., 5: 1475 1483.

\section{Aliakbarlu J; Mohammadi $S$ and Khalili S (2013):}

A Study on antioxidant potency and antibacterial activity of water extracts of some spices widely consumed in Iranian diet. J Food Biochem ., 38: 159-166.

Ali-Shtayeh MS; Al-Assali AA and Jamous RM (2013):

Antimicrobial activity of Palestinian medicinal 
Hypolipidemic Effect of Sumac (Rhus Coriaria L) Fruit Powder and Extract on Rats Fed High Cholesterol Diet

Nagib, R.M

plants against acneinducing bacteria. African $J$ Microbiol Res., 7: 2560-2573.

\section{AL-Jassabi S and Azirun S} (2010):

The role of sumac in attenuation of microcystin-Lr-induced renal oxidative damage in $\mathrm{Balb} / \mathrm{C}$ mice, American Eurasian J. of Toxicol. Sci., 2(3): 123128.

Anwer T; Sharma M; Khan G; Iqbal M; Ali MS; Alam MS; Safhi MM and Gupta N (2013):

Rhus coriaria ameliorates insulin resistance in noninsulin-dependent diabetes mellitus (NIDDM) rats. Acta Pol. Pharm - Drug Research, 70: 861-867.

AOAC (2000):

Official methods of Analysis, Association of Official Analytical.
Attaby FA; El-Desouky MA; Maha H; Mahmoud and Ahmed YA (2013):

Antihepatotoxic Effect of Some Natural Antioxidants against Liver Damage Induced By $\mathrm{CCl} 4$ in Rats, Journal of Applied Sciences Research, 9(3): 2042-2051.

Barakat A; Al-Bataina O; Ahmed $M$ and AL-Kofahi MM (2003):

Element analysis biological studies on ten oriental spices using XRF and Ames test, $J$. Tr. Elem. Med. Biol. 17:85-90.

Beretta G; Rossoni G; Santagati NA and Facino RM (2009):

Anti-ischemic activity and endotheliumdependent vaso-relaxant effect of hydrolysable tannins from the leaves of Rhus coriaria (Sumac) in isolated rabbit heart and thoracic aorta, Planta Medica, 75: 1482-1488. 
Hypolipidemic Effect of Sumac (Rhus Coriaria L) Fruit Powder and Extract on Rats Fed High Cholesterol Diet

Nagib, R.M

Beuchamp C and Fridovich J (1971):

Superoxide dismutase Improved assay an assyapplicable to acryloamide gels. Anal Biochem. 44: 276-287.

Bohmer U (1971):

Chakraborty A; Ferk F; Colorimetric kinetic method of determination of creatinine. J. Clin. Chem. Acta., (37): 193197.

\section{Brand - Williams W;}

Cuvelier $M$ and Berset $C$ (1995):

Use of free radical method to evaluate antioxidant activity, LWT-Food Science and Technology, 28(1): 25-30.

Bursal E and Köksal E (2011):

Evaluation of Reducing Power and Radical Scavenging Activities of Water and Ethanol Extracts from Sumac (Rhus coriaria L.), Food

Research International, 44( 7): 2217-2221.

Castelli T and Levitar $Y$ (1977):

Atherogenic, indices, J.Curr Presc p39.

Simić T; Brantner A;

Dušinsk M; Kundi M; Hoelzl C; Nersesyan A and Knasmüller M (2009):

DNA-protective effects of sumach (Rhus coriaria L.), a common spice: results of human and animal studies. Mutation Research / Fundamental and Molecular Mechanisms of Mutagenesis 661:1017.

Chapman DG; Gastilla R and Campbell TA (1950):

Evaluation of protein in food: A method for the determination of protein efficiency ratio. Can. J. Biochem. Physiol.; 37: 679-686.

\section{Chapman $\mathrm{H}$ and Pratt $\mathrm{P}$} (1978): 
Hypolipidemic Effect of Sumac (Rhus Coriaria L) Fruit Powder and Extract on Rats Fed High Cholesterol Diet

Nagib, R.M

Methods of analysis

from soils, plant and

water. Univ. of

California. Div. Agric.

Sci., pp: 50.

Darwish MM (2011):

Dried Fruit Extract of Sumac (Rhus coriaria L)

Protects Albino Rats from Adverse Effects of Whole Body $\gamma$-Radiation Egypt. J. Rad. Sci. Applic., 24( 2): 271-283

Derosa G; Mugellini A; Pesce RM; D'Angelo A and Maffioli P (2015):

A study about the relevance of adding acetylsalicylic acid in primary prevention in subjects with type 2 diabetes mellitus: effects on some new emerging biomarkers of cardiovascular risk. Cardiovasc Diabetol .14:95.

Fassati $P$ and Principe L (1982):

Enzymatic colorimetric method for the determination of triglycerides, J.Clin.

Chem., (28):2077.

Fossati ; Prencipe L and Berti G (1980):

Use of 3, 5 dichloro-2hydroxyl benzene sulfonic acid /4amylphenazone chromogenic system in direct enzymatic assay of uric acid in serum and urine. Clin. Chem.; 26: 227-231.

Friedwald WT; Leve R.I. and Frederickson DS (1972):

Estimation of the concentration of lowdensity lipoprotein separated by three different methods. Clin. Chem., 18: 499-502.

Ghaleb A; Bassam A; Kamel $A$ and Farah $A$ (2006):

Antibacterial Effects of Nutraceutical Plants Growing in Palestine on Pseudomonas aeruginosa. Turk. J. Biol., 30, 239. 
Hypolipidemic Effect of Sumac (Rhus Coriaria L) Fruit Powder and Extract on Rats Fed High Cholesterol Diet

Nagib, R.M

Golzadeh M; Farhoom P and Daneshyar M (2012):

Dietary Rhus coriaria L. powder reduces the blood cholesterol, VLDL-c and glucose, but increases abdominal fat in broilers. South African J Animal Sci., 42: 398-405.

\section{Gordon TM (1977):}

HDL-cholesterol (determination after separation high-density lipoprotein lipid). Amer. J. Med. (62):707.

\section{Kamesh VK; Sumathi T (2012):}

Antihyperchoesterolemic effect of Bacopa monniera linn. On high cholesterol diet induced hypercholesterolemia in rats. Asian Pacific Journal of Tropical Medicine. 949-955.

\section{Kind PR and King EJ} (1954):

Estimation of alkaline phosphatase activity by determination of hydrolyzed phenol with aminoantipyrene. $J$.

Clin.Path., 7: 322.

Kizil S and Turk M (2010):

Microelement contents and fatty acid compositions of Rhus coriaria L. and Pistacia terebinthus L. fruits spread commonly in the south eastern Anatolia region of Turkey. Nat Prod Res. 24(1): 92-98.

\section{Knedel $M$ and Boottger $R$} (1967):

A kinetic method for determination of the activity of pseudo cholinesterase, Klin. Wochenschr., 45: 325327.

Kolovou

D;

Anagnostopoulou KK and Cokkinos DV(2005):

Pathophysiology of dyslipidaemia in the metabolic syndrome," Postgraduate Medical Journal, 81(956): 358366.

\section{Kosar M; Bozan B; Temelli $F$ and Baser KHC (2006):}


Hypolipidemic Effect of Sumac (Rhus Coriaria L) Fruit Powder and Extract on Rats Fed High Cholesterol Diet

Nagib, R.M

Antioxidant activity and phenolic composition of sumac (Rhus coriaria L.) extracts. Food Chem. 103: 952-959.

Kossah R; Nsabimana C; Zhao JX; Chen HQ; Tian FW; Zhang $\mathrm{H}$ and Chen W (2009):

Comparative study on the chemical composition of Syrian sumac (Rhus coriaria L.) and Chinese sumac (Rhus typhina L.) fruits. Pak. J. Nutr, 8: 1570: 1574.

Kossah R (2010):

Optimization of extraction of polyphenols from syrian Sumac (rhus coriaria L.) and Chinese Sumac (rhus typhina L.) fruits res. $J . \quad O f$ phytochemistery, 4: $p$. 146-153.

Kossah R; Nsabimana C; Zhang $H$ and Chen $W$ (2013):

$\begin{array}{lr}\text { Evaluation } & \text { of } \\ \text { antimicrobial } & \text { and }\end{array}$ antioxidant activities of Syrian Sumac fruit extract. $J$ Natural Products, 6: 96-102.

Lin CC; Hsu YF and Lin, TC (1998):

Antioxidant and hepatoproductive activity of punicalagin and punicalin on carbon tetrachloride induced liver damage in rats. $J$ Pharm Pharmacol. 50(7):789-94.

Madihi Y; Merrikhi A; Baradaran A; Rafieian kopaei M; Shahinfard N and Ansari R (2013):

Impact of Sumac on postprandial high-fat oxidative stress. Pak $J$ Med Sci ,29(1):340-345.

Mahidi Nazouri M; Khabjavid Z; Tafakori N B; Lookian F; Javid A; Mousavi SH and Hashemy SI (2013):

Rhus Coriaria Effect on Serum Uric Acid Level and in Vivo Xanthine Oxidase Activity in Oxonate-Induced 
Hypolipidemic Effect of Sumac (Rhus Coriaria L) Fruit Powder and Extract on Rats Fed High Cholesterol Diet

Nagib, R.M

Hyperuricemic Mice $J$. Pharm. Biomed. Sci., 3(12): 1-6.

\section{Mansoob HN (2012):}

Effect of different levels of Sumac Powder (Rhus Coriaria L.) on performance, carcass and blood parameters of broiler Chickens. Annals of Biol. Res. 2(5): 647652.

Mavlyanov M; Islambekov SY; Ismailov AI; Karimdzhanou AK and Ismalov AI (1997):

Anthocyans and organic acids of the fruits of some species of Sumac. Chem Natural Compounds, 33: 209.

\section{Mohammadi S; Kouhsari}

\section{SM and Feshani AM} (2010):

Antidiabetic properties of the ethanolic extract of Rhus coriaria fruits in rats. Daru. 18(4):270274.
Ohkawa H; Ohishi N and Yagi K (1979):
Assay for
lipid peroxides in animal tissues by thiobarbituric acid reaction. Anal Biochem.; 95: 351-358.

\section{Onkar S; Mohammed A and Nida $A$ (2011):}

New antifungal aromatic compounds from the seeds of Rhus coriaria L. Inter Res J Pharmacy, 2: 188-194.

Özcan M and Haciseferogullari A (2004):

A condiment [Sumac (Rhus Coriaria L.) fruits]: Some physiochemical properties. J. Plant. Physiol. 30:74-84.

\section{Özcan MM and Akbulut M (2007):}

Estimation of minerals, nitrate and nitrite contents of medicinal and aromatic plants used as spices, condiments and herbal tea. Food. Chem. 106:852-858. 
Hypolipidemic Effect of Sumac (Rhus Coriaria L) Fruit Powder and Extract on Rats Fed High Cholesterol Diet

Nagib, R.M

Panico A; Cardile V;

Santagati NA and Messina

R (2009):

Antioxidant and

protective effects of

Sumac Leaves on

chondrocytes.

Medicinal Plants Res., 3: 855-861.

\section{Patton CJ and Crouch SR} (1977):

Enzymatic colorimetric method to determination of urea in serum. Anal. Chem., 49: 464.

\section{Pourahmad J; Eskandari}

MR; Shakibaei $\mathbf{R}$ and Kamalinejad MA (2010):

Search for hepatoprotective activity of aqueous extract of Rhus coriaria L. against oxidative stress cytotoxicity. Food Chem. Toxicol. 48( 3): 854-858.

\section{Reeves PG; Nielsen FH} and Fahmy GG (1993):

AIN-93. Purified diets for laboratory rodents: Final report of the American Institute of
Nutrition adhoc wriling committee on the reformulation of the AIN-76 A Rodent diet. J. Nutrition, 123: 1939-151.

Reiner $\mathrm{Z}$ and Tedeschi RE (2006):

Atherosclerosis - a paradox of Eastern European countries. Atherosclerosis 7: 461.

Reitman S and Frankel S (1957):

Determination of glutamate pyruvate transaminase and glutamate oxaloacetate transaminase. Amer. J. Clin. Path., 28: 56-63.

Richmond N (1973):

Colorimetric method of determination of total cholesterol and high density lipoprotein cholesterol (HDLc). Clin.Chem, 19, 13501356.

Roberts CK; Barnard RJ; Sindhu RK; Jurczak M; 
Hypolipidemic Effect of Sumac (Rhus Coriaria L) Fruit Powder and Extract on Rats Fed High Cholesterol Diet

Nagib, R.M

Ehdaie A and Vaziri ND (2006):

Oxidative stress and dysregulation of NAD $(\mathrm{P}) \mathrm{H}$ oxidase and antioxidant enzymes in diet induced metabolic syndrome. Metabolism, 55: 928-934.

Shabir A (2012):

Rhus coriaria linn, a plant of medicinal, nutritional and industrial Importance: a review. $J$ Animal \& Plant Sci, 2 (2): 505-512.

Shafiei M; Nobakht $M$ and Moazzam AA (2011):

Lipid-lowering effect of Rhus coriaria L. (sumac) fruit extract in hypercholesterolemic rats. Pharmazie 66: 988992.

Singh DP; Kondepudi KK; Bishnoi $M$ and Chopra $K$ (2014):
Altered Monoamine
Metabolism in High Fat
Diet
Induced
Neuropsychiatric
Changes in Rats. J Obes

Weight Loss Ther 4(4):

1-5.

Singleton VL; Orthofer R and Lamuela-Raventos RM (1999):

Analysis of total phenols and other oxidation substrates and antioxidants by means of Folin-Ciocalteu reagent. Methods Enzymol. 299: 152-178.

Snedecor GW and Cochran, WG (1967):

Statistical Methods.7th Ed., the Iowa State University Press, Ames, Iowa, U.S.A.

Zainab S; Salil A and Salih H (2016):

Histological and Physiological study of the effect of prazosin hydrochloride on liver and kidney of rats (Rattus norvegicus); International Journal of PharmTech Research; 8(10): 72-80 .

Zargham $H$ and Zargham R (2008): 
Hypolipidemic Effect of Sumac (Rhus Coriaria L) Fruit Powder and Extract on Rats Fed High Cholesterol Diet

Nagib, R.M

Tannin extracted from

Sumac inhibits vascular

smooth muscle cell

migration. Medical $J$

Malaysia, 11: 119-123.

Zhishen J; Mengcheng T

and Jianming $W$ (1999):
The determination of flavonoid contents in mulberry and their scavenging effects on superoxide radicals. Food Chem., 64: 555-559.

Table (1): Chemical composition of sumac $(\mathrm{g} / 100 \mathrm{~g})$

\begin{tabular}{|c|c|c|c|c|c|c|}
\hline Nutrients & $\begin{array}{c}\text { Moisture } \\
(\%)\end{array}$ & $\begin{array}{c}\text { Crude } \\
\text { Protein } \\
(\%)\end{array}$ & $\begin{array}{c}\text { Fat } \\
(\%)\end{array}$ & $\begin{array}{c}\text { Ash } \\
(\%)\end{array}$ & $\begin{array}{c}\text { Carbohydra } \\
\text { tes(\%) }\end{array}$ & $\begin{array}{c}\text { Crude } \\
\text { Fiber } \\
(\%)\end{array}$ \\
\hline Sumac & 13.65 & 4.93 & 16.88 & 5.09 & 59.45 & $\mathbf{1 9 . 6 1}$ \\
\hline
\end{tabular}

Data are means of three determinations

Table (2): Minerals content of sumac (mg/100g)

\begin{tabular}{|c|c|c|c|c|c|c|}
\hline Minerals & $\begin{array}{c}\text { Calcium } \\
(\mathrm{mg} / 100 \mathrm{~g})\end{array}$ & $\begin{array}{c}\text { Phosphorus } \\
(\mathrm{mg} / 100 \mathrm{~g})\end{array}$ & $\begin{array}{c}\text { Potassium } \\
(\mathrm{mg} / 100 \mathrm{~g})\end{array}$ & $\begin{array}{c}\text { Magnesium } \\
(\mathrm{mg} / 100 \mathrm{~g})\end{array}$ & $\begin{array}{c}\text { Iron } \\
(\mathrm{mg} / 100 \mathrm{~g})\end{array}$ & $\begin{array}{c}\text { Zinc } \\
(\mathrm{mg} / 100 \mathrm{~g})\end{array}$ \\
\hline Sumac & 398.9 & 123.7 & 812.5 & 85.67 & 15.32 & $\mathbf{2 . 0 3}$ \\
\hline
\end{tabular}

Data are means of three determinations 
Hypolipidemic Effect of Sumac (Rhus Coriaria L) Fruit Powder and Extract on Rats Fed High Cholesterol Diet

Nagib, R.M

Table (3): Total phenol and flavonoids and Scavenging effect of sumac extract on DPPH

\begin{tabular}{|c|c|c|c|}
\hline Variables & $\begin{array}{c}\text { T. phenol } \\
\mathrm{mg} / 100 \mathrm{~g}\end{array}$ & $\begin{array}{c}\text { T. flavonoid } \\
\mathrm{mg} / 100 \mathrm{~g}\end{array}$ & $\begin{array}{c}\mathrm{DPPH} \\
\mathrm{mmol} / \mathrm{ml}\end{array}$ \\
\hline Sumac & 4836 & 769 & $\mathbf{1 1 . 5 6}$ \\
\hline
\end{tabular}

Data are means of three determinations

Table (4): Effect of sumac powder and extract on body weight gain, feed intake and feed efficiency ratio of hypercholesterolemic rats

\begin{tabular}{|c|c|c|c|}
\hline Parameters & $\begin{array}{c}\text { Feed } \\
\text { intake } \\
\text { g/day/rat }\end{array}$ & $\begin{array}{l}\text { Body } \\
\text { weight } \\
\text { gain } \\
\text { (g) }\end{array}$ & FER \\
\hline G1: Negative Control & $\begin{array}{c}13.19 \pm \\
1.00^{\mathrm{c}}\end{array}$ & $\begin{array}{c}43.56 \pm \\
2.21^{\mathrm{c}}\end{array}$ & $\begin{array}{c}0.059 \pm \\
0.03^{\mathrm{a}}\end{array}$ \\
\hline G 2: Positive Control & $\begin{array}{c}20.30 \pm \\
0.88^{\mathrm{a}}\end{array}$ & $\begin{array}{c}48.95 \pm \\
4.89^{\mathrm{a}}\end{array}$ & $\begin{array}{c}0.043 \pm \\
0.04^{\mathrm{d}}\end{array}$ \\
\hline $\begin{array}{l}\text { G3: HCD + sumac } \\
\text { powder } 5 \%\end{array}$ & $\begin{array}{c}16.34 \pm \\
0.95^{b}\end{array}$ & $\begin{array}{c}45.56 \pm \\
3.21^{b}\end{array}$ & $\begin{array}{c}0.050 \pm \\
0.0^{b}\end{array}$ \\
\hline $\begin{array}{l}\text { G4: HCD + sumac } \\
\text { powder } 10 \%\end{array}$ & $\begin{array}{c}15.86 \pm \\
1.02^{b}\end{array}$ & $\begin{array}{c}44.19 \pm \\
3.28^{b}\end{array}$ & $\begin{array}{c}0.050 \pm \\
0.0^{b}\end{array}$ \\
\hline $\begin{array}{l}\text { G5: HCD + sumac } \\
\text { extract } 0.5 \mathrm{~g}\end{array}$ & $\begin{array}{c}18.87 \pm \\
2.5^{b}\end{array}$ & $\begin{array}{c}46.22 \pm \\
3.14^{b}\end{array}$ & $\begin{array}{c}0.044 \pm \\
0.03^{\mathrm{c}}\end{array}$ \\
\hline $\begin{array}{l}\text { G6: HCD + sumac } \\
\text { extract } 1.0 \mathrm{~g}\end{array}$ & $\begin{array}{c}17.60 \pm \\
1.80^{\mathrm{b}}\end{array}$ & $\begin{array}{c}45.01 \pm \\
3.26^{b}\end{array}$ & $\begin{array}{c}0.046 \pm \\
0.02^{\mathrm{c}}\end{array}$ \\
\hline
\end{tabular}

Means \pm standard deviations in the same column with different letters are significantly different $(P \leq 0.05)$ 
Hypolipidemic Effect of Sumac (Rhus Coriaria L) Fruit Powder and Extract on Rats Fed High Cholesterol Diet

Nagib, R.M

Table (5): Effect of sumac powder and extract on lipids profile of hypercholesterolemic rats

\begin{tabular}{|c|c|c|c|c|c|c|}
\hline $\begin{array}{l}\text { Parameters } \\
\text { Groups }\end{array}$ & $\begin{array}{l}\text { T. Ch } \\
\text { mg/dl }\end{array}$ & $\begin{array}{l}\text { T.G. } \\
\text { mg/dl }\end{array}$ & $\begin{array}{c}\text { HDL-c } \\
\mathbf{m g} / \mathbf{d l}\end{array}$ & $\begin{array}{l}\text { LDL-c } \\
\mathbf{m g} / \mathbf{d l}\end{array}$ & $\begin{array}{l}\text { VLDL- } \\
\mathrm{c} \\
\mathbf{m g} / \mathbf{d l}\end{array}$ & $\begin{array}{l}\text { Atherogenic } \\
\text { Index } \\
\text { Cholesterol/ } \\
\text { HDLc }\end{array}$ \\
\hline $\begin{array}{l}\text { G1: Negative } \\
\text { Control }\end{array}$ & $\begin{array}{r}77.30 \\
\pm 3.66^{\mathrm{c}}\end{array}$ & $\begin{array}{c}81.84 \\
\pm 3.65^{c}\end{array}$ & $\begin{array}{c}41.75 \\
\pm \underset{b}{1.13}\end{array}$ & $\begin{array}{r}19.18 \\
\pm 1.23^{\mathrm{c}}\end{array}$ & $\begin{array}{c}16.37 \\
\pm 1.08^{b}\end{array}$ & $\begin{array}{c}1.85 \\
\pm 0.098^{b}\end{array}$ \\
\hline $\begin{array}{l}\text { G2: Positive } \\
\text { Control }\end{array}$ & $\begin{array}{l}156.69 \\
\pm 4.98^{a} \\
\end{array}$ & $\begin{array}{r}166.58 \\
\pm 3.69^{\text {a }} \\
\end{array}$ & $\begin{array}{c}31.48 \\
\pm 1.87^{\mathrm{c}} \\
\end{array}$ & $\begin{array}{r}91.89 \\
+5.67^{\mathrm{a}} \\
\end{array}$ & $\begin{array}{c}33.32 \\
\pm 1.82^{\text {a }} \\
\end{array}$ & $\begin{array}{c}4.98 \\
\pm 0.076^{\mathrm{a}} \\
\end{array}$ \\
\hline $\begin{array}{l}\text { G3: HCD + sumac } \\
\text { powder } \mathbf{5 \%}\end{array}$ & $\begin{array}{c}84.12 \\
\pm 4.45^{b}\end{array}$ & $\begin{array}{c}82.46 \\
\pm 4.54^{b}\end{array}$ & $\begin{array}{r}41.55 \\
\pm 1.54^{b}\end{array}$ & $\begin{array}{c}26.08 \\
\pm 2.44^{b}\end{array}$ & $\begin{array}{c}16.49 \\
\pm 1.33^{\mathrm{b}}\end{array}$ & $\begin{array}{c}2.02 \\
\pm 0.052^{b}\end{array}$ \\
\hline $\begin{array}{l}\text { G4: HCD + sumac } \\
\text { powder } \mathbf{1 0 \%}\end{array}$ & $\begin{array}{c}80.28 \\
\pm 4.11^{\mathrm{b}}\end{array}$ & $\begin{array}{r}81.90 \\
\pm 4.43^{c}\end{array}$ & $\begin{array}{c}42.47 \\
\pm 1.32^{\text {a }}\end{array}$ & $\begin{array}{c}21.43 \\
\pm 1.34^{\mathrm{c}}\end{array}$ & $\begin{array}{c}16.38 \\
\pm 1.12^{\mathrm{b}}\end{array}$ & $\begin{array}{c}1.89 \\
\pm 0.023^{b}\end{array}$ \\
\hline $\begin{array}{l}\text { G5: HCD + sumac } \\
\text { extract } 0.5 \mathrm{~g}\end{array}$ & $\begin{array}{r}79.67 \\
\pm 1.99^{c}\end{array}$ & $\begin{array}{c}83.36 \\
\pm 2.55^{\mathrm{b}}\end{array}$ & $\begin{array}{c}39.12 \\
\pm 2.11^{\mathrm{b}}\end{array}$ & $\begin{array}{c}23.88 \\
\pm 2.01^{\mathrm{b}}\end{array}$ & $\begin{array}{c}16.67 \\
\pm 1.64^{b}\end{array}$ & $\begin{array}{c}2.04 \\
\pm 0.056^{\mathrm{b}}\end{array}$ \\
\hline $\begin{array}{l}\text { G6: HCD + sumac } \\
\text { extract } 1.0 \mathrm{~g}\end{array}$ & $\begin{array}{c}77.19 \\
\pm 2.19^{\mathrm{c}}\end{array}$ & $\begin{array}{c}80.52 \\
\pm 1.96^{\mathrm{c}}\end{array}$ & $\begin{array}{c}43.61 \\
\pm 2.03^{\mathrm{a}}\end{array}$ & $\begin{array}{c}17.48 \\
\pm 3.22^{\mathrm{c}}\end{array}$ & $\begin{array}{c}16.10 \\
\pm 1.11^{\mathrm{b}}\end{array}$ & $\begin{array}{c}1.77 \\
\pm 0.054\end{array}$ \\
\hline
\end{tabular}

Means \pm standard deviations in the same column with different letters are significantly different $(P \leq 0.05)$ 
Hypolipidemic Effect of Sumac (Rhus Coriaria L) Fruit Powder and Extract on Rats Fed High Cholesterol Diet

Nagib, R.M

Table (6): Effect of sumac powder and extract on kidney functions of hypercholesterolemic rats

\begin{tabular}{|l|c|c|c|}
\hline Groups & $\begin{array}{c}\text { Uric acid } \\
\mathbf{m g} / \mathbf{d l}\end{array}$ & $\begin{array}{c}\text { Urea } \\
\mathbf{m g} / \mathbf{d l}\end{array}$ & $\begin{array}{c}\text { Creatinine } \\
\mathbf{m g} / \mathbf{d l}\end{array}$ \\
\hline G1: Negative Control & $1.73 \pm$ & $18.75 \pm$ & $1.27 \pm$ \\
& $0.26^{\mathrm{c}}$ & $1.13^{\mathrm{c}}$ & $0.01^{\mathrm{b}}$ \\
\hline G2: Positive Control & $3.87 \pm$ & $28.48 \pm$ & $2.75 \pm$ \\
& $0.81^{\mathrm{a}}$ & $1.87^{\mathrm{a}}$ & $0.11^{\mathrm{a}}$ \\
\hline G3: HCD + sumac & $2.46 \pm$ & $23.95 \pm$ & $1.75 \pm$ \\
powder 5\% & $0.15^{\mathrm{b}}$ & $1.54^{\mathrm{b}}$ & $0.13^{\mathrm{b}}$ \\
\hline G4: HCD + sumac & $1.97 \pm$ & $21.41 \pm$ & $1.45 \pm$ \\
powder 10\% & $0.17^{\mathrm{c}}$ & $1.08^{\mathrm{b}}$ & $0.12^{\mathrm{b}}$ \\
& & & \\
\hline G5: HCD + sumac & $2.01 \pm$ & $20.51 \pm$ & $1.49 \pm$ \\
extract 0.5 g & $0.62^{\mathrm{b}}$ & $2.03^{\mathrm{b}}$ & $0.02^{\mathrm{b}}$ \\
& & & \\
\hline G6: HCD + sumac & $1.81 \pm$ & $19.62 \pm$ & $1.38 \pm$ \\
extract 1.0 g & $0.27^{\mathrm{c}}$ & $2.11^{\mathrm{c}}$ & $0.12^{\mathrm{b}}$ \\
& & & \\
\hline
\end{tabular}

Means \pm standard deviations in the same column with different letters are significantly different $(P \leq 0.05)$ 
Hypolipidemic Effect of Sumac (Rhus Coriaria L) Fruit Powder and Extract on Rats Fed High Cholesterol Diet

Nagib, R.M

Table (7): Effect of sumac powder and extract on liver functions of hypercholesterolemic rats

\begin{tabular}{|l|c|c|c|}
\hline \multicolumn{1}{|c|}{ Parameters } & $\begin{array}{c}\text { ALT } \\
\boldsymbol{\mu} / \mathbf{m l}\end{array}$ & $\begin{array}{c}\text { AST } \\
\boldsymbol{\mu} / \mathbf{m l}\end{array}$ & $\begin{array}{c}\text { ALP } \\
\boldsymbol{\mu} / \mathbf{m l}\end{array}$ \\
\hline G1: Negative Control & $\begin{array}{c}29.35 \pm \\
1.12^{\mathrm{d}}\end{array}$ & $\begin{array}{c}51.17 \pm \\
5.81^{\mathrm{d}}\end{array}$ & $\begin{array}{c}44.17 \pm \\
5.66^{\mathrm{d}}\end{array}$ \\
\hline G2: Positive Control & $46.55 \pm$ & $79.39 \pm$ & $60.38 \pm$ \\
& $3.35^{\mathrm{a}}$ & $9.61^{\mathrm{a}}$ & $5.81^{\mathrm{a}}$ \\
\hline G3: HCD + sumac & $35.17 \pm$ & $57.25 \pm$ & $50.73 \pm$ \\
powder 5\% & $2.01^{\mathrm{b}}$ & $6.15^{\mathrm{b}}$ & $4.37^{\mathrm{b}}$ \\
\hline G4: HCD + sumac & $33.84 \pm$ & $55.64 \pm$ & $47.34 \pm$ \\
powder 10\% & $0.74^{\mathrm{b}}$ & $4.25^{\mathrm{c}}$ & $5.01^{\mathrm{c}}$ \\
\hline G5: HCD + sumac & $34.23 \pm$ & $59.14 \pm$ & $48.54 \pm$ \\
extract 0.5 g & $2.61^{\mathrm{b}}$ & $8.10^{\mathrm{b}}$ & $3.11^{\mathrm{c}}$ \\
\hline G6: HCD + sumac & $31.11^{\mathrm{c}}$ & $55.11^{\mathrm{c}}$ & $46.91 \pm$ \\
extract 1.0 g $^{3}$ & $3.65^{\mathrm{c}}$ & $4.13^{\mathrm{c}}$ & $3.20^{\mathrm{c}}$ \\
\hline
\end{tabular}

Means \pm standard deviations in the same column with different letters are significantly different $(P \leq 0.05)$ 
Hypolipidemic Effect of Sumac (Rhus Coriaria L) Fruit Powder and Extract on Rats Fed High Cholesterol Diet

Nagib, R.M

Table (8): Effect of sumac powder and extract on TNF $\alpha$, MDA, SOD and Acetylcholine esterase (AChE) of hypercholesterolemic rats

\begin{tabular}{|c|c|c|c|c|}
\hline $\begin{array}{l}\text { Parameters } \\
\text { Groups }\end{array}$ & $\begin{array}{l}\text { TNF } \alpha \\
\text { pg/ml }\end{array}$ & $\begin{array}{r}\text { MDA } \\
\boldsymbol{\mu} \mathbf{m o l} / \mathbf{l}\end{array}$ & $\begin{array}{r}\text { SOD } \\
(\boldsymbol{\mu} / \mathbf{m l})\end{array}$ & $\begin{array}{c}\text { Acetylcholine } \\
\text { esterase } \\
(\mathrm{AChE}) \\
\boldsymbol{\mu m o l} / \mathbf{m l}\end{array}$ \\
\hline $\begin{array}{l}\text { G1: Negative } \\
\text { Control }\end{array}$ & $\begin{array}{c}1.12 \\
\pm 0.35^{\mathrm{d}}\end{array}$ & $\begin{array}{l}1.54 \pm \\
0.54^{\mathrm{c}}\end{array}$ & $\begin{array}{c}30.97 \pm \\
0.54^{\mathrm{a}}\end{array}$ & $\begin{array}{c}3.54 \pm \\
0.2^{\mathrm{c}}\end{array}$ \\
\hline $\begin{array}{l}\text { G2: Positive } \\
\text { Control }\end{array}$ & $\begin{array}{l}3.99 \pm \\
0.58^{a}\end{array}$ & $\begin{array}{l}4.79 \pm \\
0.65^{\mathrm{a}}\end{array}$ & $\begin{array}{c}20.54 \pm \\
0.71^{c}\end{array}$ & $\begin{array}{l}7.15 \pm \\
0.4^{\mathrm{a}}\end{array}$ \\
\hline $\begin{array}{l}\text { G3: HCD + } \\
\text { sumac powder } \\
\mathbf{5 \%}\end{array}$ & $\begin{array}{l}2.34 \pm \\
0.66^{b}\end{array}$ & $\begin{array}{l}2.64 \pm \\
0.37^{b}\end{array}$ & $\begin{array}{c}25.49 \pm \\
0.54^{\mathrm{b}}\end{array}$ & $\begin{array}{l}5.12 \pm \\
0.6^{b}\end{array}$ \\
\hline $\begin{array}{l}\text { G4: HCD + } \\
\text { sumac powder } \\
10 \%\end{array}$ & $\begin{array}{l}2.02 \pm \\
0.36^{b}\end{array}$ & $\begin{array}{l}2.38 \pm \\
0.32^{b}\end{array}$ & $\begin{array}{c}27.85 \pm \\
0.25^{b}\end{array}$ & $\begin{array}{l}4.82 \pm \\
0.7^{\mathrm{b}}\end{array}$ \\
\hline $\begin{array}{l}\text { G5: HCD + } \\
\text { sumac extract } \\
0.5 \mathrm{~g}\end{array}$ & $\begin{array}{l}1.89 \pm \\
0.68^{c}\end{array}$ & $\begin{array}{l}2.93 \pm \\
0.35^{b}\end{array}$ & $\begin{array}{c}26.98 \pm \\
0.84^{b}\end{array}$ & $\begin{array}{l}4.89 \pm \\
0.4^{b}\end{array}$ \\
\hline $\begin{array}{l}\text { G6: HCD + } \\
\text { sumac extract } \\
\mathbf{1 . 0} \mathrm{g}\end{array}$ & $\begin{array}{l}1.72 \pm \\
0.57^{c}\end{array}$ & $\begin{array}{l}2.11 \pm \\
0.58^{b}\end{array}$ & $\begin{array}{l}29.52 \pm \\
0.28^{\text {ab }}\end{array}$ & $\begin{array}{l}3.96 \pm \\
0.7^{c}\end{array}$ \\
\hline
\end{tabular}

Means \pm standard deviations in the same column with different letters are significantly different $(P \leq 0.05)$ 
Hypolipidemic Effect of Sumac (Rhus Coriaria L) Fruit Powder and Extract on Rats Fed High Cholesterol Diet

Nagib, R.M

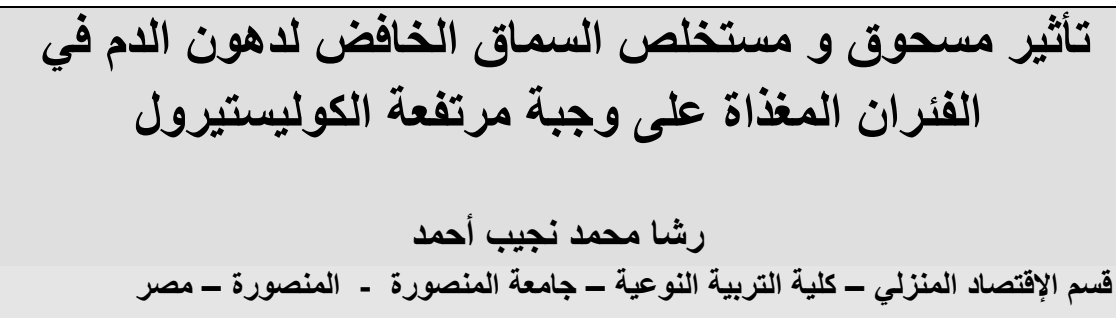

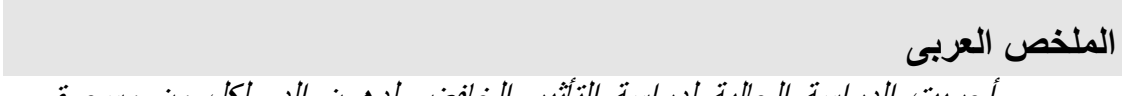

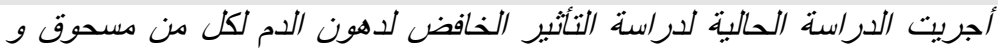

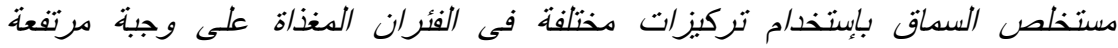

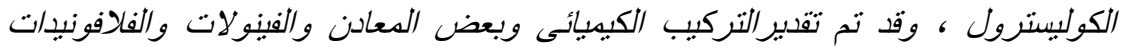

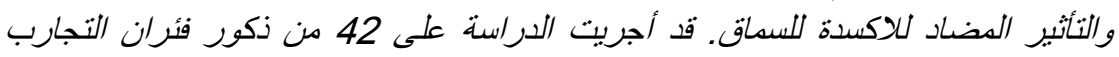

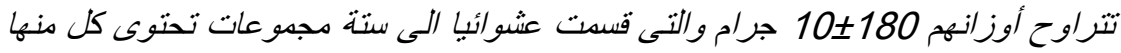

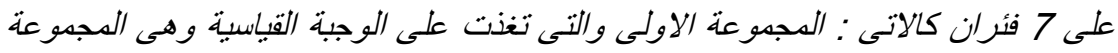

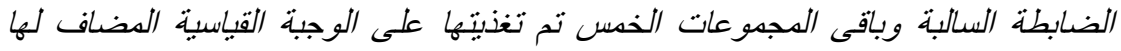

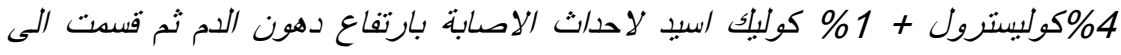

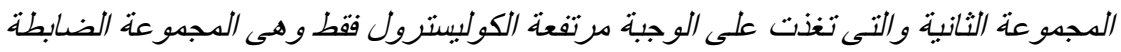
الموجبة والمجدوعة الثالثة والرابعة وقد تم تغذبتهم على الوجبة مرتفعة الكوليبترول

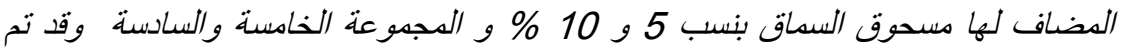

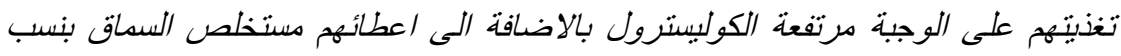

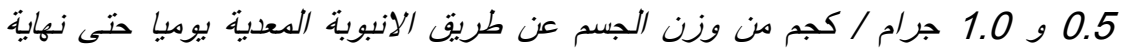

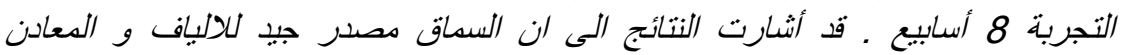

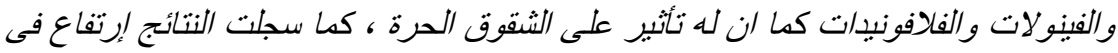

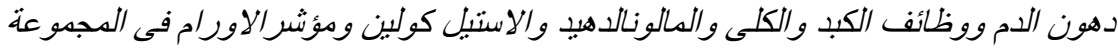

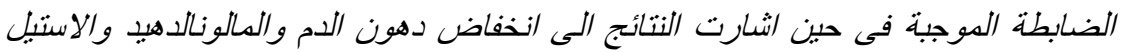

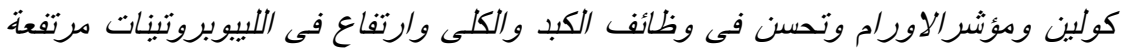

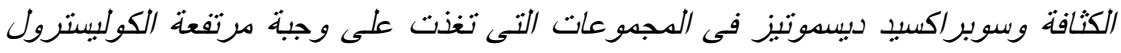
والتى عولجت بهسحوق ومستخلص السماق خاصا عند /ستخد/م نسب 10 \% مسحوق و 1.0

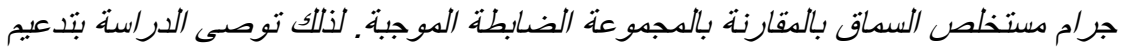

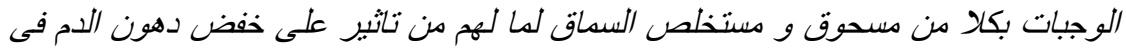
الفئرلن النوحان.

الكلمات المفتاحية : السماق ، ارتفاع الكولبيترول ، دهون الدم ، وظائف الكبب والكلى ، الثقوق الحرة 